\title{
Government policy effects on cattle and wildlife ranching profits in Zimbabwe
}

\author{
URS P. KREUTER AND JOHN P.WORKMAN
}

\begin{abstract}
Authors are research associate, Department of Rangeland Ecology and Management, Texas A\&M University, College Station, 77843-2126; and professor, Department of Range Science, Utah State University, Logan, 84322-5230. The research was conducted under the auspices of the WWF Multispecies Animal Production Systems Project in Harare. Zimbabwe.
\end{abstract}

\begin{abstract}
The profitability of alternative range-based production systems is frequently affected by government policies. Moreover, the comparative profitability of wild and domestic animal production systems on African semi-arid savannas has not been well analyzed. This paper presents a simple method for analyzing government policy effects on ranch profits and reports application of the method to 30 commercial cattle, 7 wildlife, and 13 mixed ranches in Zimbabwe. Ranches were selected in 4 contiguous woodland savanna areas with abundant wildlife and in 2 adjacent open savanna areas with sparse wildlife. Financial profits were calculated from 1989/90 ranch data and economic profits were estimated from the opportunity costs of inputs and outputs. A policy analysis matrix was used to estimate financial-economic profit difierences. Cattle ranches in the 2 areas with sparse wildlife were the most profitable group studied. Profits were lower (but similar) for cattle and mixed ranches in the areas with abundant wildlife. The financial profit was higher than economic profit for all ranch types, thus creating production disincentives. However, currency over-valuation and implicit taxes on exported beef created greater production disincentives for cattle than wildlife producers. While the policy interventions negated the government's stated objectives of increasing foreign currency earnings and being self sufficient in beef production, they did appear to have beneficial range management consequences by encouraging fewer cattle on historically overstocked cattle ranches.
\end{abstract}

Key Words: Economic profit, financial profit, production incentives, rangeland allocation, semi-arid savannas.

Governments regularly intervene in economies as they attempt to achieve particular policy goals. One sector in which almost all governments intervene is agriculture where they try to alter income distributions, stabilize prices, promote food self-sufficiency, or protect their own agriculturalists from world market forces. But these interventions may fail to achieve their goals and can produce unintended

\footnotetext{
Funding for the research was provided by the World Wide Fund for Nature (Switzerland), Rothmans of Pall Mali (Zimbabwe), and the Political Economic Research Center (Montana). The authors are grateful for their
}

consequences, one reason being that market prices influenced by policy interventions may not accurately reflect resource scarcity and may thus encourage economically inefficient resource use (Monke and Pearson 1989).

Given the widespread dependence of Africans on semi-arid savanna resources for their livelihood, efficient and sustainable use of such rangelands is critical for human welfare. Yet, these ecosystems are being increasingly degraded under traditional agricultural practices and increasing human population pressure. Due to their relatively low production potential, economic analyses of the use of such rangelands have, however, been rare and little attention has been paid to government policy effects on land-use patterns. This deficiency will not promote future human welfare.

Semi-arid African savannas provide a heterogeneous forage base which multi-species herbivore communities defoliate more uniformly than cattle alone (Walker 1979; Taylor and Walker 1978). It has thus been argued that game ranching should be more profitable than beef ranching in such areas (Dasmann and Mossman 1961; Clarke et al. 1985; Hopcraft 1986; Child 1988) and that game ranching may be ecologically the most sustainable form of land-use (Child and Child 1986).

Such claims have, however, been based on incomplete economic analyses, virtually none of which have accounted for government policy effects on profitability. Yet simple analytical tools, such as the Policy Analysis Matrix (PAM)(Monke and Pearson 1989), have been used to identify policy-based profit distortions in agronomic production systems. Such distortions tend to promote economically inefficient resource allocation for production because producers tend to oversupply commodities whose profits are inflated by policy interventions and undersupply those with suppressed profits (Masters 1989).

This paper presents the financial profits of cattle and wildlife ranching in Zimbabwe, and it describes the use of the PAM methodology to analyze the effects of government policy on the economic efficiency of these ranches. Since it has a long history of cattle ranching and legislation allowing landowners to commercially use wildlife on their property, Zimbabwe provided an ideal venue for a comparative economic study of semi-arid range use in Africa. Data were collected from commercial ranches in the Midlands Province, which contains the country's most productive semi-arid savannas. Less than $2 \%$ of the Midlands is arable but 78\% is grazeable (Roth 1990) making it suitable primarily for extensive animal production (Vincent and Thomas 1960). 


\section{Study Description}

\section{Survey Popultion and Sample}

A survey of independent ranches, where revenue was derived from cattle or wildlife, or both was conducted during 1990/91. The study population was restricted to independent ranches exceeding 1,200 ha (70\% of all ranches in the Midlands) because, smaller ranches could not sustain 240 livestock units, the probable minimum herd size for viable commercial cattle enterprises in Zimbabwe. Six agricultural areas with high concentrations of commercial ranches were selected for study. Four were dominated by Miombo woodland savanna with abundant wildlife while the other 2 consisted of mainly open, Hyparrhenia-dominated grasslands, with low densities of wild ungulates.

Fifty ranches were selected for study ranging in size from 1,424 to $132,840 \mathrm{ha}$. In the 4 areas with abundant wildlife, data were obtained from most (ca. 80\%) of the relevant ranches, including 15 cattle ranches 7 wildlife ranches and 13 ranches with both cattle and wildlife enterprises. In the 2 areas with sparse wildlife, no revenue was derived from wildlife, and 15 cattle ranches (ca. 25\%) were randomly selected for study. Data were collected for the $1989 / 90$ production season through personal interviews using a standardized survey questionnaire.

Surveyed cattle ranchers derived virtually all of their income from the sale of beef cattle. Among wildlife enterprises $84 \%$ provided revenue from the sale of safari hunting opportunities, $25 \%$ from hunting leases, and $25 \%$ from the sale of game meat. Hunting clients were 49\% American, 40\% European and 6\% Australian, and hunted species included leopard (Panthera pardus) or sable (Hipotragus niger), as the main trophy species, and numerous other plains game species.

\section{Analytical Framework}

Both financial and economic profits were calculated for each ranch. Financial profit is the actual profit determined by market prices of inputs and outputs and reflects policy distortions. It was calculated from the financial records of each ranch. Economic profit is, by contrast, a hypothetical concept and a function of the opportunity costs of inputs and outputs (Jansen 1989). Such costs reflect resource scarcity values which are independent of government policy interventions. Assuming that financial profits account for all costs including production externalities, financial-economic profit differences thus approximate government policy effects on operational profitability.

The Policy Analysis Matrix (PAM) approach described by Monke and Pearson (1989) was used to estimate the differences between financial and economic profit estimates. One criticism of the PAM method has been that it is theoretically limited for assessing economic efficiency because the indices used to estimate profit are average parameters (Masters 1989). Estimation of economic efficiency dictates the use of marginal rather than average profits. However, where there were many producers with relatively constant short-term returns to scale (as in the case of ranching enterprises), average and marginal values are very similar.

In using a PAM to estimate financial and economic profits, inputs and outputs are separated into tradeable and domestic factors of production. Tradeable inputs are all those which can be traded internationally. Domestic factors of production are those commodities for which international migration is constrained. They include capital, labor, and land.

\section{Estimating Economic Prices of Tradeable Commodities}

World prices were used as a proxy for the economic prices (opportunity costs) of tradeable commodities because, due to international market competition, they may be assumed to be free of national policy interventions (Monke and Pearson 1989). The relevant world prices for exports are the free on board (f.o.b.) border prices, and for imports, the cost, insurance, freight (c.i.f.) import prices (Gittinger 1982). These border prices were obtained from official sources where possible. Where the border price of a tradeable commodity was unobtainable, the commodity's economic price was estimated by subtracting transfer payments, such as subsidies and taxes, from its average financial price.

To convert international economic prices of tradeable goods to domestic values, free-market exchange rates must be used (Jansen 1989). During the survey period, the Zimbabwe dollar (Z\$) was overvalued relative to that of its main trading partners (Masters 1990) resulting in a black-market exchange rate of double the official rate. Since black-market rates include a risk premium, the mean of the official and the black-market rates was considered to be a conservative estimate of the free-market rate (Jansen 1989, Jansen et al. 1992), representing 50\% overvaluation of the Z\$. In summary, economic prices for tradeable commodities were calculated from the world/market price conversion ratio, the foreign content percentage, and the $\mathrm{Z} \$$ overvaluation correction factor as shown in Table 1.

\section{Estimating Economic Prices of Domestic Factors of Production}

The economic values of domestic factor prices (land, labor and capital) are determined from their domestic opportunity cost (Monke and Pearson 1989). In this analysis, management and land costs were excluded and profits were measured as net returns to investment in management and land. Declared management fees were disregarded because they were distorted by income tax structures. Average land prices were imprecise due to wide fluctuations resulting from mandated land redistribution (Murphree and Cumming 1991) and restrictive foreign investment policies.

\section{Net Revenue Adjustments}

Since data were collected for 1 year only, adjustments were made to the net cattle revenues to eliminate capitalization of profits or liquidation of capital through changes in cattle herd sizes. Wildlife revenues were not adjusted in the same way because population changes of wild animals on individual ranches were difficult to detect. Eighty percent of wild-animal purchase costs were, however, added back to wildlife revenue since such purchases were irregular and the financial returns from them were assumed to accrue over a 5-year period. Revenues and costs associated with the use of wildlife outside of the Midlands were also excluded.

Table 1. Parameters used to estimate the ZS economic prices of tradeable commodities.

\begin{tabular}{ccccccccc}
\hline \hline $\begin{array}{c}\text { Financial } \\
\text { price }\end{array}$ & $\begin{array}{c}\text { Price } \\
\text { ratio }\end{array}$ & & $\begin{array}{c}\text { Foreign } \\
\text { content }\end{array}$ & $\begin{array}{c}\text { Forex } \\
\text { factor }\end{array}$ & \multicolumn{3}{c}{ Economic price } \\
\hline A & B & C & D & E & F & G \\
& & & & & & local & Total \\
\hline
\end{tabular}

$A=$ Financial value of tradeable output or input (Z\$)

$\mathrm{B}=$ world/market price ratio (economic conversion factor)

$\mathrm{C}=\%$ foreign content of financial value

$\mathrm{D}=\mathrm{Z} \$$ overvaluation correction factor

$\mathrm{E}=$ economic price of the foreign content (Z\$)

$F=$ economic price of the local content (Z\$)

$\mathbf{G}=$ total economic price of tradeable output or input (ZS). 


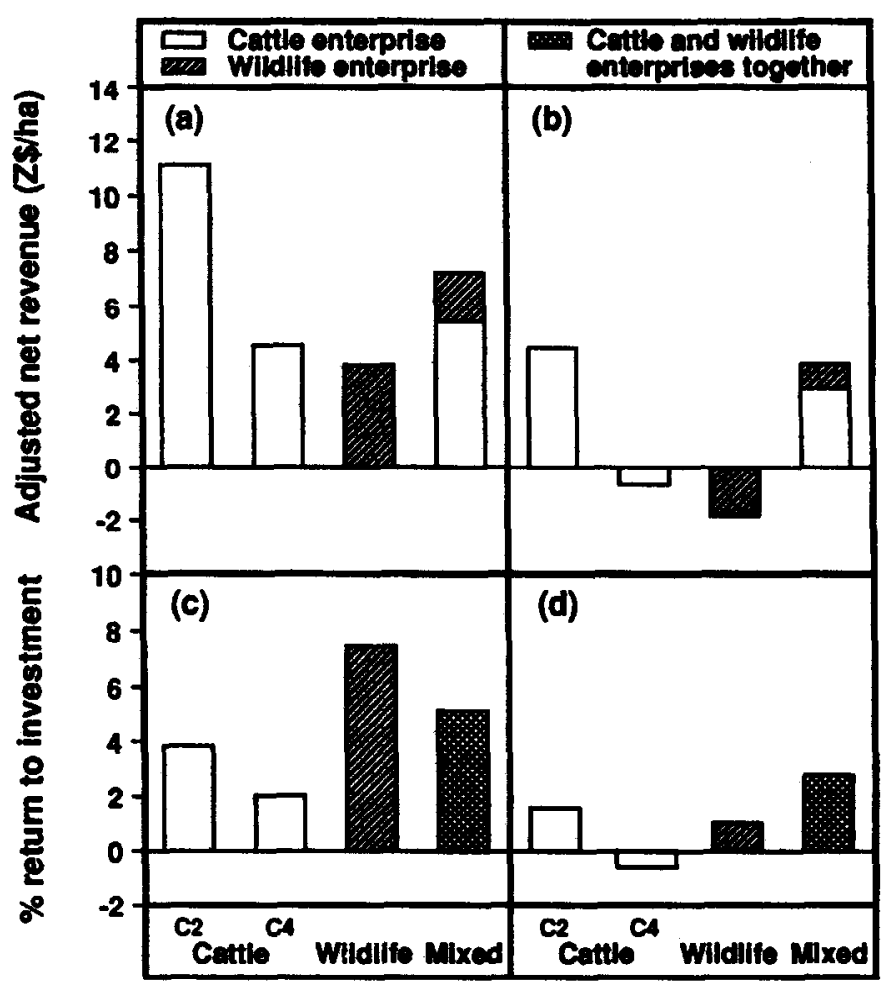

Ranch type

Fig. 1. Financial profits of cattle, wildlife and mixed ranches. [(a) per-ha excluding depreciation, (b) per-ha including depreciation, (c) $\%$ return to investment excluding depreciation, and (d) \% return to investment including depreciation; $\mathrm{C2}$ and $\mathrm{C} 4$ are cattle ranches in areas with sparse and abundant wildlife].

\section{Data Analyses}

Uncertainity about the domestic opportunity cost of capital, overvaluation of the $\mathrm{ZS}$, and cattle-revenue price ratios, required the use of sensitity analyses to determine the effects of assumed values on economic profitability estimates. The small sample size (7-15) of each ranch category and differences in sample variance required the use of non-parametric statistics (Wilcoxon mateched pair and the Mann-Whitney 2 sample tests) to compare sample means (Hollander and Wolve 1973).

\section{Results}

Average financial and economic profits for 2 categories of cattle ranches (C2 - in areas with sparse wildlife and $\mathrm{C} 4$ - in areas with abundant wildlife), wildlife ranches and mixed ranches are presented. Results are presented in 3 parts: financial profitability; financial-economic profit comparisons; sensitivity analysis of capital opportunity cost, $\mathbf{Z \$}$ overvaluation and cattle-revenue price ratio on economic profits.

\section{Financial profitability}

The average financial profit of each ranch category is reported here as a reference point for the subsequent discussion of policy effects on profitability. Since capital asset values were uncertain, financial profits were calculated both with and without estimated asset depreciation (Fig. 1).

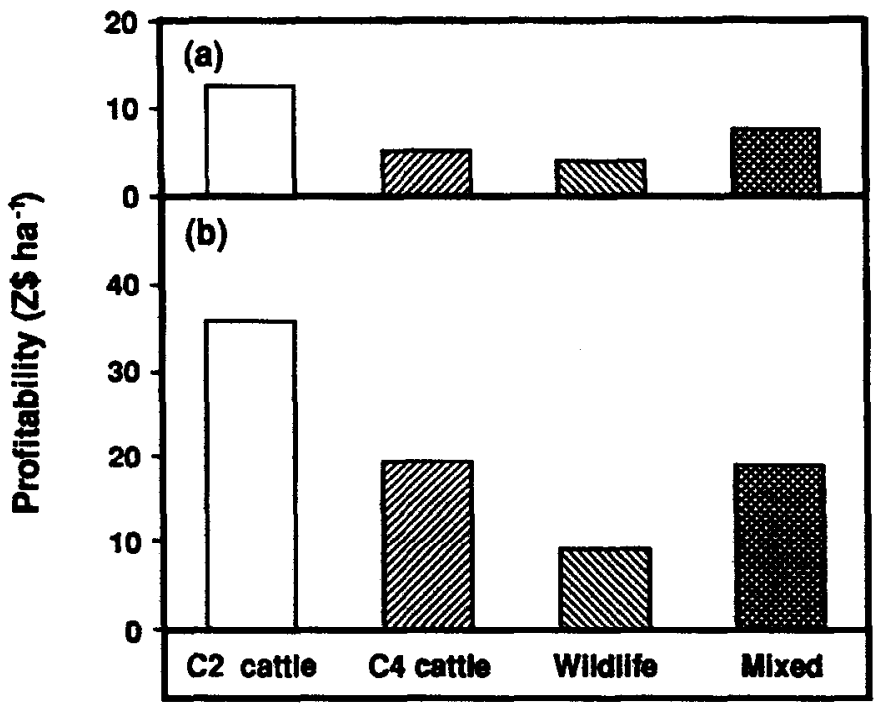

\section{Ranch type}

Fig. 2. Comparison of (a) financial and (b) economic profits based on $0 \%$ capital opportunity cost, $50 \% \mathrm{ZS}$ overvaluation and 1.25 beef-revenue conversion factor.

When depreciation costs were excluded, all 4 ranch types provided positive net returns ha-1 (Fig. 1a: $\mathrm{C} 2$ cattle Z\$11.18, $P<0.01 ; \mathrm{C} 4$ cattle $\mathrm{Z} \$ 4.53, P<0.05$; wildlife $\mathrm{Z} \$ 3.79, P<0.10$; mixed $\mathrm{Z} \$ 7.20, P<$ 0.01 ) and positive returns to investments (Fig. 1c: C2 cattle $3.86 \%$, $P<0.01$; C4 cattle $2.03 \%, P<0.10$; wildlife $7.42 \%, P<0.05$; mixed $5.16 \%, P<0.01$ ). Due to the small sample sizes, few inter-category profit differences were statistically significant, though net revenue $\mathrm{ha}^{-1}$ on $\mathrm{C} 2$ cattle ranches was significantly greater than on $\mathrm{C4}$ cattle and wildlife ranches $(P<0.05)$ (Fig. 1 a) and the $\%$ returns to investment was greater for wildlife than $C 4$ cattle ranches $(P<0.10)($ Fig. 1c).

When depreciation was included, the financial profits of all ranch categories were significantly reduced $(P<0.01)$, only $C 2$ cattle and mixed ranches providing positive net revenues ha. ${ }^{1}$ (Fig. 1b: $\mathrm{C} 2$ cattle $\mathrm{Z} \$ 4.50$, mixed $\mathrm{Z} \$ 3.88, P<0.10$ ) and only mixed ranches providing significant positive returns to investments (Fig. 1d: mixed $2.78 \%, P<$ $0.10)$. Net revenue ha ${ }^{-1}$ was greater $(P<0.10)$ on $C 2$ cattle ranches than on $\mathrm{C} 4$ cattle and wildlife ranches (Fig. 1b) and the returns to investments on mixed ranches was greater $(P<0.10)$ than on $\mathrm{C} 4$ cattle ranches (Fig. 1d). Comparison of Fig. 1a and $1 \mathrm{~b}$ shows that only the $\mathrm{C} 2$ cattle ranches and the mixed ranches were financially viable when depreciation was accounted for. It also suggests that $\mathbf{C} 2$ cattle and wildlife ranchers were, on average, living off depreciation or borrowings to survive financially, neither of which are sustainable practices. Having examined the financial profits of cattle, wildlife and mixed ranches in the Midlands, the next section examines how profitable these ranches might have been without government policy interventions.

\section{Financial-Economic Profit Comparisons}

For the initial comparison of financial and economic profits, the following parameter values were used to calculate economic profits: $0 \%$ capital opportunity cost, $50 \% \mathrm{Z} \$$ overvaluation and 1.25 cattle-price conversion ratio. The "real" opportunity cost for capital was assumed to be $0 \%$ because the $10 \%$ nominal interest rate on savings accounts (the "next best" investment opportunity) was similar to the prevailing 


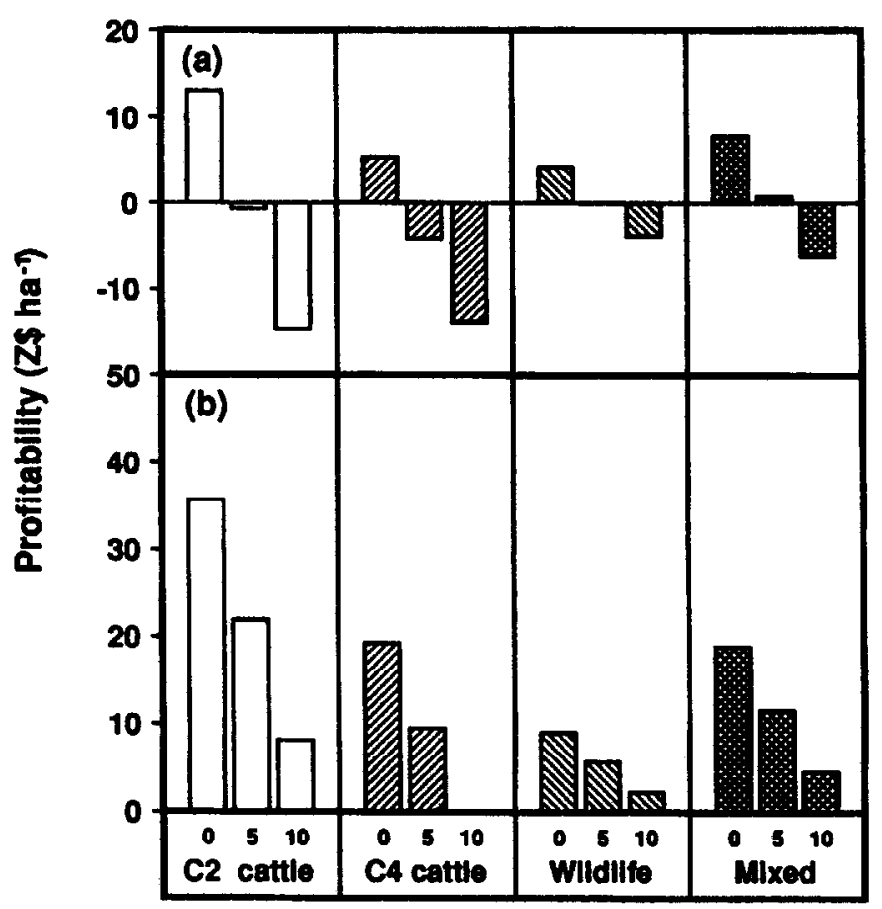

\section{Capital interest rate by ranch type}

Fig. 3. Effects of assumed capital opportunity cost on (a) financial profitability and (b) economic profitability of ranches. [Assumed capital opportunity costs are $0 \%, 5 \%$ and $10 \%]$.

inflation rate ( $12.6 \%$ as measured by the consumer price index). The free-market exchange rate for the $\mathrm{Z} \$$ was taken to be the average of the official and black-market exchange rates. The 1.25 cattle-price conversion factor was the ratio of the beef-sales realization of the Cold Storage Commission (CSC - Zimbabwe's central beef marketing authority) and the producer price weighted by the 1990 export and local sales values (Jansen et al. 1992). This conversion value reflected a $25 \%$ implicit tax on beef revenue due to Zimbabwe's policy of partial retention of earnings from lucrative beef sales to the European Community (World Bank 1990) to provide an average annual $12 \%$ subsidy for meat consumption by low-income consumers between 1985 and 1991 (Jansen et al. 1992).

The economic profits derived using the above conversion parameter values are compared with financial profits (excluding depreciation) in Figure 2. Converting financial to economic prices significantly increased the profits of all ranches $(P<0.01$ except wildlife $P<0.05)$, the increases were greater $(P<0.05)$ for cattle than wildlife ranches. This was because the average financial revenue of cattle and mixed ranches was greater than on wildlife ranches $(P<0.01)$ and the conversion factor for beef revenue was greater than for wildlife revenue. In addition, financial-economic price conversions increased revenue more than costs in all ranch categories $(P<0.01$, wildlife $P<0.05$ ).

These results imply that the prevailing policy mix (which resulted in an overvalued $\mathrm{ZS}$ and $25 \%$ implicit taxes on beef producer prices, and high inflation rates) was creating negative production incentives for all ranchers, particularly cattle ranchers. Both cattle and wildlife were thus possibly being produced at levels below those that would prevail in a policy-neutral climate. In the 4 areas with wildlife, this conclusion was supported by declining cattle herds in the 1980's and a shift to less capital intensive wildlife ranching (Child 1988).

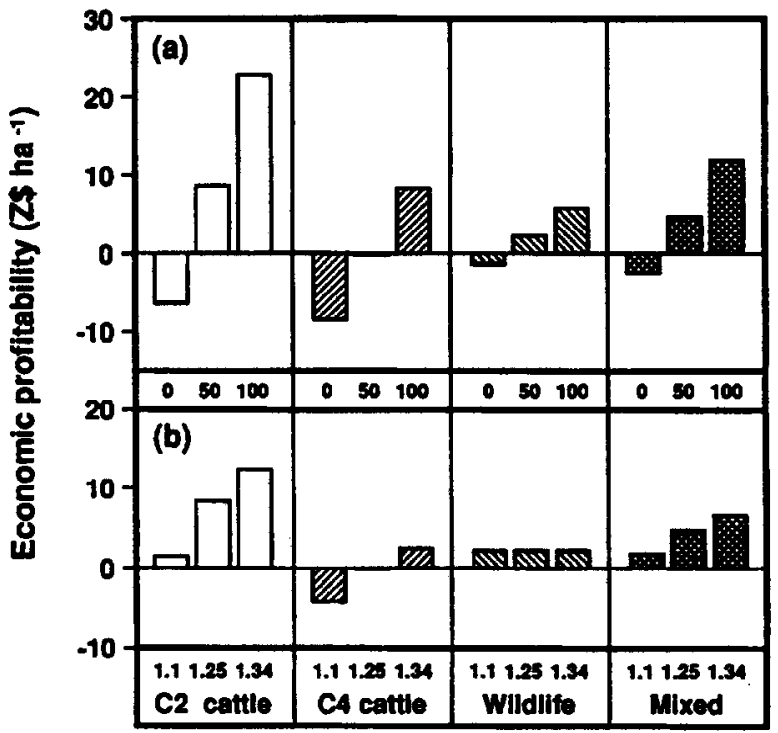

\section{ZS overvaluation and beef-price conversion factor by ranch type}

Fig. 4. Effects of assumed (a) $\mathbf{Z S}$ over-valuation and (b) cattle-revenue price ratio on the economic profitability of ranches. [Assumed ZS overvaluation values are $0 \%, 50 \%$, and $100 \%$; assumed cattle-revenue price ratios are 1.1, 1.25, and 1.34].

However, in areas with sparse wildlife, ranchers appeared to be increasing their herds. In the prevailing inflationary climate they might have had a short-term incentive to increase herd size because the speculative returns on holding cattle appeared to be greater than returns from alternative savings investments.

\section{Sensitivity Analysis}

The sensitivity of profit estimates to capital opportunity cost, Z\$ exchange rate and the cattle-revenue price ratio was analyzed using three separate values for each parameter. Changing the capital interest rate impacted both financial and economic profit estimates, but varying the latter 2 parameters affected only economic profit estimates.

\section{Capital Opportunity Cost}

The 3 capital opportunity costs used in the sensitivity analysis were $0 \%, 5 \%$ and $10 \%$. Zero percent is the assumed "real" opportunity cost previously used, $10 \%$ was the average interest rate on savings accounts in Zimbabwe during the survey period, and $5 \%$ is an intermediate value, similar to the real discount rate recommended for use in the economic analysis of range improvement projects in the USA (Workman 1986, p 200). The mean financial and economic profits ha $^{-1}$ at each level of capital opportunity cost are presented in Figure 3.

Financial profits calculated using $0 \%$ capital cost (Fig. 3a) are identical to those in Figure 2a. When these estimates were adjusted for $10 \%$ capital interest, the average values for each ranch category were all negative with cattle ranches sustaining greater losses $(P<$ 0.05 ) than mixed and wildlife operations. While economic profits similarly decreased with increasing capital opportunity cost (Fig. 3b), they remained positive for all ranch categories at $10 \%$ capital interest. The use of $5 \%$ capital cost resulted in intermediate financial and economic profit estimates.

Estimated profits of cattle ranches (especially C2 ranches) were more sensitive to the assumed capital opportunity cost than those of the other ranch categories. This was due largely to inter-group differ- 
ences in livestock investments; wildlife "assets" being assigned zero capital value because they are state owned and do not represent personal wealth. Yet, despite the inter-ranch differences of capital interest effects on financial and economic profits, the financial-economic profit disparities were only slightly affected by changing the capital interest rate because, for each level of capital interest, the aggregate capital opportunity cost of a ranch was similar in financial and economic terms. This implies that the previous conclusion, that government policy was creating negative production incentivies for all ranchers, is robust with respect to assumed capital interest.

\section{ZS Overvaluation}

The $3 \mathrm{Z \$}$ overvaluation rates used in the sensitivity analysis were $0 \%, 50 \%$, and $100 \%$. The 1st rate assumes that the free-market rate was equal to the official exchange rate and the 3 rd rate represents the prevailing black-market exchange rate relative to the official rate, The 2 nd rate is intermediate between the first 2 and reflects an assumed 50\% risk premium in the black-market rate.

Increasing the $\mathrm{Z} \$$ overvaluation rate (Fig. 4a) significantly increased $(P<0.01$ except wildlife $P<0.05)$ the estimated economic profits of all ranch categories, but the effect was greater $(P<0.01)$ for cattle than wildlife ranches. This difference was mainly due to the greater price ratio for cattle revenue than wildlife revenue, each of which was multiplied by the $\mathrm{Z} \$$ overvaluation factor to estimate their economic revenues (see Table 1).

These results imply that, with increasing overvaluation of the Z\$, cattle enterprises faced an increasing level of implicit taxation relative to wildlife enterprises because overvaluation effects on net earnings in local currency is greater in cattle than wildlife enterprises. If other policy interventions remained constant, use of a free-market exchange rate would thus enhance the profitability of beef production more than wildlife ranching, and might lead to a production shift away from wildlife to beef.

\section{Cattle-Revenue Price Ratio}

The 3 ratios were used to convert cattle revenue from financial to economic prices were $1.10,1.25$, and 1.35. As previously described, the 1.25 conversion factor was the CSC-beef-sales-realization/producer-price ratio weighted by actual export and local sales values in 1990. The value of 1.10 was derived using 1989 beef production and price statistics. The 1.35 factor was derived from 1990 statistics but using an adjusted value for export earnings to eliminate the effects of foot-and-mouth disease related export restrictions in 1989/90.

Increasing the cattle-revenue conversion factor (Fig. 4b) significantly increased $(P<0.01)$ the economic profits of cattle enterprise, especially $\mathrm{C} 2$ cattle ranches. This implies that the policy of taxing beef export earnings to subsidize consumers had resulted in increasingly greater production disincentives for cattle producers compared with wildlife ranchers between 1989 and 1990. This increase would have been greater if beef exports had not been constrained by the outbreak of foot-and-mouth disease. However, the economic profit differences between cattle and wildlife ranches might have been considerably less if Zimbabwe did not have access to the European Community market.

\section{Discussion}

In semi-arid savannas land use is often restricted to domestic and wild animal production due to erratic and limited rainfall. Investment patterns in the use of these rangelands vary according to the relative productivity, capital investment requirements, and risk of different animal production systems. In the prevailing uncertain economic cli- mate in Zimbabwe, direct foreign currency earning potential was also an important determinant of investment decisions.

In the 2 Midlands areas with sparse wildlife, cattle ranching was the only viable range-based production option due to predominance of herbaceous vegetation and a lack of suitable habitats for diverse wildlife communities. Cattle ranches in these areas were financially and economically the most profitable group studied. In the 4 areas with abundant wildlife, mixed ranches were at least as profitable as cattle ranches. Based on 1989/90 data, movement from purely cattle to purely wildlife operations resulted in lower profits but also lower capital investments in livestock (Kreuter 1992).

Government policy interventions produced an overvalued $\mathbf{Z} \$$ and an implicit tax on export beef prices. This created negative production incentives for both beef and wildlife ranchers, but these effects were greater for cattle enterprises. Removing the meat subsidization policy might thus result in a shift from wildlife to cattle ranching, assuming that the access to the lucrative European Community market can be retained by Zimbabwe.

Since the wildlife industry was unregulated, safari hunting provided the potential for direct foreign currency earnings. This, together with the fact that diversification spread risk without significantly increasing capital costs, made it rational for cattle ranchers to incorporate wildlife enterprises. For example, beef producers faced recurrent foot-and-mouth related marketing disruptions while potential socio-political instability presented risks to tourist-orientated wildlife enterprises (Cumming 1989). In addition, most ranchers stated that long-term overstocking with cattle was the major factor causing increased rangeland degradation and soil erosion in the Midlands. Since mixed ranches were stocked lower than cattle ranches (Kreuter and Workman 1994), the prevailing policy-driven diversification incentives might inadvertently be improving range condition. The advantages of mixed ranching appear to be reflected by an increase in the number of wildlife enterprises on former cattle-only ranches during the 1980's (Child 1988).

Government regulation of national beef prices resulted in increased beef supply to unregulated rural markets and decreased sales to the central beef marketing authority from nearly $90 \%$ of production in 1980 to about $50 \%$ in 1990 (AMA 1991). This created meat shortages in some urban areas and reduced beef exports. The production disincentives were thus counteracting the government's stated objectives of maximizing net foreign currency earnings (Zimbabwe 1991) and being self-sufficient in beef production (Rodriguez 1985). By adopting free-market $\mathrm{Z} \$$ exchange rates and free-market input and output prices, the state is likely to increase the profitability of all ranches, particularly cattle ranches. This might partially offset the diversification trend.

\section{Conclusion}

Claims that wildlife can provide greater profits than cattle in semiarid savannas have been based mainly on financial analyses of wildlife systems which included valuable big game species, such as buffalo. The Midlands lacks buffalo due to their veterinary conflicts with cattle, the dominant range animal. In areas with abundant wildlife cattle and mixed ranches were similarly profitable, both financially and economically. Since diversification from cattle to mixed ranching spread risk and reduced stocking rates, mixed ranches appeared to be financially, economically and ecologically optimal where wild animals were abundant. Where possible, rangelands in the Midlands should therefore be managed not only to produce a dense herbaceous community for grazers but a diversity of browse also. 
Our results emphasize the need to qualify claims that wildlife ranching is more profitable than cattle ranching in African semi-arid savanna ecosystems. Our results also showed that economic studies of policy effects on range-resource allocation can illuminate compatibility or conflict between stated policy objectives, actual policy effects, and economically efficient rangeland allocation.

\section{Literature Cited}

AMA. 1991. Beef situation and outlook report 1990-91. Agricultural Marketing Authority, Harare, Zimbabwe.

Child, B. 1988. The role of wildlife utilization in the sustainable economic development of semi-arid rangelands in Zimbabwe. Phd. Thesis, Univ. Oxford.

Child, B., and G. Child. 1986. Wildlife, economic systems and sustainable human welfare in semi-arid rangelands in Southern Africa. In: Proc. FAO/Finland Watershed Management Workshop. Maseru, Lesotho.

Clarke, V.J., D.H.M. Cumming, R.B. Martin, and D.A. Peddie. 1985. The comparative economics of African wildlife and extensive cattle production, p. 87-96. In: Proc. FAO African Forestry and Wildlife Meeting. Bamako,Mali.

Cumming, D.H.M. 1989. Commercial and safari hunting in Zimbabwe, p. 147-169. In: R.J. Hudson, K.R. Drew, and L.M. Baskin (eds.), Wildlife production systems. Cambridge Univ. Press, Cambridge.

Dasmann, R.F. and A.S. Mossman. 1961. Commercial utilization of game mammals on a Rhodesian ranch. Wild Life 3:7-14.

Gittinger, J.P. 1982. Economic analysis of agricultural projects (2nd Edition). Econ. Development Inst., World Bank, Baltimore.

Hollander, M.H. and D.A. Wolfe. 1973. Nonparametric statistical methods. Wiley and Sons, N.Y.

Hopcraft, D. 1986. Wildlife land-use: A realistic alternative, p. 93-101. In: Proc. Wildlife/livestock interfaces on rangeland (ed. S. MacMillan), InterAfrican Bur. Anim. Resources. Nairobi, Kenya.

Jansen, D.J., B. Child, and I. Bond. 1992. Cattle, wildlife, both or neither: Results of a financial and economic survey of commercial ranches in Southern Zimbabwe. WWF Multispecies Anim. Prod. Systems Project Rep. 30. Harare, Zimbabwe.
Kreuter, U.P. 1992. Comparative economics of cattle and wildlife ranching in the Zimbabwe Midlands. Ph.D. Diss., Utah State Univ. Logan.

Kreuter, U.P. and J.P. Workman. 1994. Costs of overstocking on cattle and wildlife ranches in Zimbabwe. Ecol. Econ. in press.

Masters, W.A. 1989. The policy analysis matrix in Zimbabwe: A methodological introduction. Dep. Agr. Econ. and Ext. Rep. AEE6/89, Univ. Zimbabwe. Harare, Zimbabwe.

Masters, W.A. 1990. The value of foreign exchange in Zimbabwe: Concepts and estimates. Dep. Agr. Econ. and Ext. Rep. AEE2/90, Univ. Zimbabwe. Harare, Zimbabwe.

Monke, E.A., and S.C. Pearson. 1989. The policy analysis matrix for agricultural development. Cornell Univ. Press. Ithaca, N.Y.

Murphree, M.W. and D.H.M. Cumming. 1991. Savanna land use: Policy and practice in Zimbabwe. CASS/WWF Rep. 1, Univ. Zimbabwe. Harare, Zimbabwe.

Rodriguez, G. 1985. The economic implications of the beef pricing policy in Zimbabwe. LPU Rep. 7, Int. Livestock Center for Africa. Addis Ababa, Ethiopia.

Roth, M.J. 1990. Analysis of agrarian structure and land-use patterns. Agricultural Memorandum Background Paper, World Bank. Harare, Zimbabwe.

Taylor, R. and B. Walker. 1978. Comparison of vegetation use and herbivore bio-mass on a Rhodesian game and cattle ranch. J. Applied Ecol. 15:565-581.

Vincent, V., and R.G. Thomas. 1960. An agricultural survey of Southern Rhodesia. Government Printer, Harare, Zimbabwe.

Walker, B.H. 1979. Game ranching in Africa. p. 55-82. In: B.H. Walker (ed), Management of semi-arid ecosystems. Elsevier Scientific, Amsterdam.

Workman, J.P. 1986. Range Economics. Macmillan, N.Y.

World Bank. 1990. Price prospects for major primary commodities, 1990 to 2005. Volume II: Agricultural products, fertilizers and tropical timber. World Bank, Washington, DC.

Zimbabwe. 1991. Zimbabwe: A framework for economic reform. Government Printer, Harare, Zimbabwe. 